\title{
\#instalanguage, THE LATEST TRENDS IN THE POLISH LANGUAGE AS A RESULT OF THE EXPANSION OF DIGITAL FORMS OF COMMUNICATION
}

\author{
Gabriela Piechnik?
}

\begin{abstract}
The publication presents how the Internet and new trends in modern communication influence the Polish language. Digital forms of communication provoke people to use language shortcuts, borrowings and make users do not care about language correctness. The author attempts to outline the future development of the Polish language.
\end{abstract}

Key words: language trends, communication, netspeak

\section{Introduction}

Mikołaj Rej wrote - "Let it by all and sundry foreign nations be known

that Poles speak not Anserine but a tongue of their own" [Rej, 1562]. Rej was the first Polish author to write exclusively in the Polish language. He proposed that Poles should break with tradition, current in the Renaissance, of writing in Latin [Malinowski, 2003]. Nowadays, it seems that Poles forget to take care of their native tongue again. The greatest language revolution started in the 20th century and deepened in the 21st century. The influence of Americanism, postmodernism, and consumerism can be noticed. Also, some political and economic changes that took place in Poland at the end of the 20th century had an impact on the Polish language [Ożóg, 2004]. The IT revolution and the development of the new media also have played a significant role.

The purpose of this text is to find the answer to the question how modern online communication and new trends affect the Polish language? Most Polish linguists have focused on the impact of short text messages, chats, e-mails and instant messengers [Ożóg, 2004; Dzioba, 2005; Grzenia, 2007]. Nowadays, it is also worth to look at social media such as the increasingly popular Instagram, Twitter, and Snapchat. In addition to the main research problem, additional questions appeared: how literature has changed under the influence of modern forms of communication and how the latest trends have changed the daily interaction among people. 


\section{Changes in language}

Language not only creates our reality, but it undoubtedly reflects the latest developments. It continually shows all the changes of customs, economics, culture, and politics. An evident rebuilding of the language was also visible in Poland, mostly in the 1980s and 90s [Ożóg, 2004, p. 16]. The events that took place in the country during that period resulted in the consolidation of new terms, the introduction of new words, and the emergence of influences that are constantly affecting the Polish language. From the linguistic point of view, the turn in the 90 s left the Polish language with the most significant change. For Polish speakers, those changes were associated with the substantial and rapid development of the native language.

After changes in political system and abolition of censorship, the Poles changed their approach to the mother tongue. The Polish language was no longer the most important asset that had to be protected from the occupant [Grybosiowa, 2003]. It should also be noted that the transformation of the political system has led to another change - the centrally planned economy has given a way to the free market. Both of those processes, in turn, caused the economic revolution. In a short time, Poles had to name thousands of new things, institutions, products, phenomena, and processes. In the emergence of new words, several processes that are widely described by Kazimierz Ożóg, Antonina Grybosiowa or Władysław Lubaś can be distinguished. ${ }^{2}$ The most important are: word formation, borrowings and giving new meanings to the "old" names, thus creating neosemanticism. Other, but not less important reasons for changes occurring in the Polish language, include extremely fast-growing media and consumer culture, which Poles have become unable to adapt fully. Linguists agree on one thing - the media have largely contributed to the vulgarization, computerization, and monetization of the Polish language. Vulgarization may be a threat to the Polish language and disruption of communication between people. The media promote the "strong man" model, whose attribute is vulgar vocabulary [Ożóg, 2004, p. 44-45].

\section{New trends}

Currently, the Internet is becoming the fastest source of delivering new lexemes and a new sense of meanings. It seems that nowadays photos and hashtags are enough to communicate. In his reflections, Rafał Dzioba emphasizes that the language of the Internet consists of five basic Internet situations. At the end of 2003 it was possible to specify:

1. e-mails,

2. websites,

3. chats and instant messengers,

4. role-playing games,

5. other combinations [Dzioba, 2005, p. 463].

However, the Internet is growing too fast for those five online situations to remain up-to-date. Currently, it seems that there is a need to add to the list a few positions connected with an image like Instagram and Snapchat. More and more people communicate with pictures and words become hashtags, for example, \#instalanguage, \#instapic, \#photooftheday. Hashtags are a kind of road signs in the Internet, where hash is the symbol "\#" and tag means the keyword [Oxford English Dictionary]. Each such combination of sign and expression can carry a lot of information. First hashtags were used to em-

\footnotetext{
2 K. Ożóg in "Polszczyzna przełomu XX i XXI wieku: wybrane zagadnienia”, W. Lubaś in „Polszczyzna wobec najnowszych przemian społecznych”, [in:] Miodek J. (red.), O zagrożeniach i bogactwie polszczyzn, A. Grybosiowa in article „Dynamika zmian językowych o podłożu kulturowym u progu XXI wieku (na materiale polskim)".
} 
phasize the importance of particular content. They were also used in chatting - to enter a room or topic, it was necessary to write, for example, \#rzeszow to go into the Rzeszow Regional Room [Grzenia, 2007, p.34]. Later, a Twitter was created, where hashtags became more popular. Message from one American, Chris Messina, in August 2007 said: "What do you think about using the \# sign and thus grouping the discussions?". The idea appealed to users and day by day the number of entries tagged with the \# symbol was getting bigger. The first serious test of the hashtags was a forest fire in the San Diego area. The Internet users marked their posts \#sandiegofire. That allowed people who were looking for the information about the disaster to click on \#sandiegofire to preview all messages tagged in this way. That particular situation proved that such postings could work [Gąsior, 2013] Hashtags are currently used in topics about art, culture, sport, and politics. They can be used by online communities, but also by event organizers who just post a keyword associated with the event. Thanks to this, photos, tweets and Facebook posts are grouped under one word. Then there is an exchange of views, and it often gives a possibility to ask questions to the person in charge [Kopeć, 2015]. The Internet users are the leaders in inventing keywords.

People describe their pictures only by tagged words, they no longer use sentences. For example: "\#PolishCabaretNight \#PodpromieHall \#Rzeszow \#2017 \#laughing \#cabarets \#EveryonelnForm" which in free translation can mean: "I went to the Polish Cabaret Night in 2017. The event took place in the Podpromie Hall, in Rzeszow. It was funny. All cabarets are in shape." Another example is: "\#with @username \#in \#SlovakParadise \#TatraMountains \#chillout \#view \#40km \#onfoot", which may mean that the sender of this message relaxes in the Tatra Mountains, exactly in the Slovak Paradise, hiking $40 \mathrm{~km}$ on foot and admiring the beautiful views.

Hashtags force users to use contractions, lose punctuation and other rules of correct sentences. Since hashtags are an American creation, borrowings from English to the Polish language are apparent and inevitable. Correctness is not the most important; the most important is time. Borrowings and acronyms are often very economical [Sandorska, Szłapiński, 2016], which makes the senders not care about correctness. Most often, however, such communication is effective, because most people (especially the youth) know right away what the sender wants to convey. The hashtags are so powerful that they appear even in places where they cannot be clicked. However, they encourage to browse the Internet using a given keyword. ${ }^{3}$

The Internet is a place where everything that is liked by most of the users instantly becomes a trend. It can be a random entry, a meme or a photo. But this kind of fame does not last long. Time shows that the Internet users get bored quickly and look for new things that would entertain them. Here, it is essential to explain what a meme is. Providing unambiguous definition of this phenomenon is impossible. It can be defined as arbitrary, catchy information that takes many forms. Therefore, memes appear as pictures, videos, sentences, and even single words [Walkiewicz, 2012]. Regardless of what shape and pattern they have, one condition is constant - they are popular on the web. One of the first typical memes was the photo of so-called Grumpy Cat. The signatures under the photo were used in the daily communication of young people, and basically, it was mainly about the message creation scheme itself.

Thanks to the Internet, such words as SWAG and YOLO also spread fast. In youth slag SWAG means promoting yourself with expensive and visible jewelry, branded clothes, and luxury etc. [Miejski Słownik Slangu i Mowy Potocznej]. YOLO stands for You Only Live Once. It suggests that especially young people should not care about the future and the consequences of their actions, everything is allowed because they live only once [Quote Investigator]. From those words, there is also the hashtag \#SWAG (129568 699 
public posts on Instagram on 25th November 2017) and \#YOLO (26 990190 posts). The entries refer to too many things to be able to state the situations that they can be used for.

The above examples are only a small part of the phenomenon that dynamically changes the language of electronic communication. Most online memes and hashtags have their origins from across the ocean but they are adapted to the Polish language very fast, which may create a real threat - especially nowadays, when young people do not understand the need to use their native tongue properly. For teenagers, the message speed and efficiency is essential. Showing that one can use the latest trends (communication tools), makes contact with peers easier. [Skudrzyk, 2014]. The value of the content and its correctness is of the secondary importance.

Many linguists claim that language creates our reality. However, it can be said that there is a mutual influence. Each social group uses a specific code, which may be incomprehensible for people outside this group. Particular words refer to the lifestyle of a given group, gender, age, etc.

\section{Literature under the influence of changes}

All changes occurring in the Polish language are visible not only in everyday communication but also in the literature. In the past, the literature could be used as an ideal example of the correct Polish language. Today's literature is a reflection of the language used by ordinary people and sometimes should not be disseminated and perpetuated in the minds of recipients in this form. The difference between the literary style of the nineteenth and twentieth century is enormous. In the first case, there is a visible care about the language: lengthy sentences, a variety of stylistic means, extensive colorful descriptions and plasticity of language. In the second case, a pervasive everyday language is dominant. There is a lot of colloquialisms and vulgarisms. Short, simple sentences express the haste that accompanies people every day. The recipients do not focus their attention on the multiple-folded sentences in which colorful descriptions predominate. What is important now is the action and the main character's thoughts. That vast difference is apparently due to the changes that have taken place in societies, but also due to the Poles' attitude to the language. In Poland, the mother tongue used to be honored more because of the danger of the loss of national independence. Nowadays, people are fascinated by freedom of expression, the West, and modernity. They do not care for the mother tongue, because the correct use of language is time-consuming, and above all - unfashionable. It also requires intellectual effort. There is a belief that a modern and educated man should use a lot of extraneous inclusions.

\section{Methodology and conclusions}

Conclusions are based on the preliminary literary analysis and the comparison of selected books:

- a fragment of the poem Pan Tadeusz by Adam Mickiewicz, due to its richness of stylistic means and the fact that the whole piece is written in the so-called Polish alexandrine $^{4}$. It is also one of the most important literary works in Poland,

- a fragment of a novel Nad Niemnem by Eliza Orzeszkowa, due to the beautiful, colorful and extensive descriptions of nature,

- a fragment of a book titled Ja Wam pokażę! by Katarzyna Grochola - one of the most popular books published in Poland in the 21 st century, which bravely describes the experiences of the main character,

- a fragment of the book by Tomasz Sekielski - Sejf, due to powerful language, which

$4 \quad$ - a type of metrical line used in traditional Polish poetry and verse drama. 
reflects the present times by the use of vulgarisms, colloquialisms, and borrowings.

During the analysis, the linguistic richness of the nineteenth-century literature is immediately apparent. Modern literary works probably do not have so many metaphors, sublime apostrophes, colorful descriptions and plastic epithets, as in several verses of the "old" literature. However, they employ a greater number of neologisms, colloquialisms, and vulgarisms. They refer to common matters and are not so poetic. It can be said that an SMS style of communication is dominant, which is more attractive for the "SMS generation". Long and colorful descriptions do not attract attention the way shorter forms or images do [Goban-Klas, 2017].

The main problem discussed in this article concentrates on how modern online communication and new trends affect the Polish language. The gathered examples show that what seems to be nowadays essential is to write quickly and briefly, without paying attention to the correct spelling or punctuation. Sentences almost do not exist; they are replaced by single words or associations. There is also more and more vulgarity and borrowings in this language.

The analysis also shows that the literature has become much poorer in its form. The sophisticated style of nineteenth-century works has turned into every day, colloquial, often vulgar style of twenty-first-century books. The subject of works remains similar, although in the nineteenth century it was mainly about the nation. Love stories and disputes were secondary topics. Nowadays the love theme, action, and conflicts are the central themes of the written novels. Narration in books is usually conducted in the first person singular. Characters are usually associated with the media or the advertising industry. The focus is mainly on the characters' emotional states, what they see and what they want. The science-fiction genre, in which the authors describe technological gadgets used by the characters, also become popular. Writers, however, do not refer to their visionary descriptions of the future (as in the novels of S. Lem). The time interval has been considerably shortened. Authors present improved technologies that are already known. The described societies are entangled in complex computer networks, also often imaginary worlds and characters are introduced [Świech, 2003, p. 99-100].

The primary question was how other trends described in the Polish language influence literature and everyday communication. The influence of Americanization and consumerism is visible. Borrowings and English inclusions also appear in literature, e-mail correspondence, and instant messaging conversations.

\section{An attempt to outline the future of the Polish language}

Obtained information helps to make some predictions about changes in the language. Current trends are already mentioned many times within this article, i.e., the vulgarity of speech, borrowings, foreign words, abbreviations or the use of emoticons. Emoticons are also seen in handwritten notes, which can be treated as a return to visual communication. Applications that use images and hashtags (Instagram or Snapchat) are even more powerful examples of changes in language and communication. Shortcuts, creative use of letters and punctuation, acceptance for lack of linguistic correctness, and wordplay are all the characteristics of the netspeak. The term, which was initially used in a closed group of hackers, is now used to describe the language of the web [Górska-Olesińska, 2003, p. 111-118]. Probably there will be even more borrowings from other languages, and the frequency of using foreign phrases will increase. The best known example of this tendency is the so-called corpospeak ${ }^{5}$.

\footnotetext{
Corpospeak is a jargon used in corporations. In Poland, it is also called ponglish, because it often mixes English words with Polish phrases. However, the use of corpospeak can be justified since sometimes it is easier to use already functioning in the industry English words than to create corresponding expressions in other languages.
} 
The quote of Jakub Żulczyk, Polish writer and columnist, can serve as a good summary of this paper: "[Online] we practically do not use language anymore - we have brought it to some collapsed forms and hashtags, which on the one hand are a living murder of the language, but on the other hand they perfectly reflect the character of our generation's thought processes. [The language has become] loose, shallow, flat, and associative. Hashtags show how our brains work - by using unrelated words, we do not think anymore, we just play with the associations." [Męskie Pisanie, 2013].

\section{References}

DZIOBA R. (2005), Netspeak - nową hybrydą językową, [in:] Dytman-Stasieńko A., Stasieńko J. (ed.), Język @ multimedia, Wydawnictwo Naukowe Dolnośląskiej Szkoły Wyższej Edukacji TWP, Wrocław.

GĄSIOR M. (2013), Szał hashtagów, czyli \#poconamteznaki [online 26 November 2017], http://natemat. pl/57707,szal-hashtagow-czyli-poconamteznaki.

GOBAN-KLAS T. (2007), Nadchodzące społeczeństwo medialne, Chowanna, Wydawnictwo Uniwersytetu Śląskiego, Katowice [online 27 November 2017], http://bazhum.muzhp.pl/media//files/Chowanna/Chowanna-r2007-t2/Chowanna-r2007-t2-s37-51/Chowanna-r2007-t2-s37-51.pdf.

GÓRSKA-OLESIŃSKA M. (2003), Netspeak - nowe medium, [in:] Liternet.pl, ed. P. Marecki, RABID, Kraków.

GRYBOSIOWA A. (2003), Dynamika zmian językowych o podłożu kulturowym u progu XXI wieku (na materiale polskim) [in:] Grybosiowa A., Język wtopiony w rzeczywistość, Katowice [online 26 November 2017], http:// www.poradniajezykowa.us.edu.pl/artykuly/AG_dynamika.pdf.

GRZENIA J. (2007), Komunikacja językowa w Internecie, Wydawnictwo Naukowe PWN, Warszawa.

KOPEĆ J. (2015), Hashtagi, ćwierkanie i świat jako baza danych, Antropologia Surfingu [online 26 November 2017], https://web.archive.org/web/20150406032842/http://surfing.wymiarywiedzy.pl/hashtagi-cwierkanie-i-swiat-jako-baza-danych/.

MALINOWSKI M. (2003), 0 co chodziło Rejowi... [online 26 November 2017], https://obcyjezykpolski. pl/o-co-chodzilo-rejowi/.

OŻóG K. (2004), Polszczyzna przełomu XX i XXI wieku: wybrane zagadnienia, Otwarty Rozdział, Rzeszów.

REJ M. (1562), Do tego, co czytat, [online 06.01.2018] https://obcyjezykpolski.pl/o-co-chodzilo-rejowi/

SANDORSKA J., SZŁAPIŃSKI W. (2016), Język w Internecie, uproszczony w komunikacji [online 26 November 2017], https://lingwistykapraktyczna.wordpress.com/2016/03/16/jezyk-w-internecie-uproszczony-w-komunikacji/

SKUDRZYK A., (2014), Homo videns - nowe media a język nowego pokolenia, [in:] Profilaktyka logopedyczna w praktyce edukacyjnej, T.2, ed. Węsierska K., Moćko N. , Katowice, Uniwersytet Śląski, 2014

ŚWIECH A. (2003), Internet - sposób na literaturę? Wątki internetowe w polskiej science fiction, [in:] Liternet. pl, ed. P. Marecki, RABID, Kraków.

WALKIEWICZ A. (2012), Czym są memy internetowe? Rozważania z perspektywy memetycznej, Teksty z ULICY nr 14 Zeszyt memetyczny, Katowice [online 27 November 2017], http://www.memetyka.us.edu.pl/dokumenty/pliki/zm14_2012_Walkiewicz.pdf.

Męskie Pisanie (2013), http://meskiepisanie.pl/stracone-pokolenie/, online 26.11.2017.

Miejski Słownik Slangu i Mowy Potocznej, http://www.miejski.pl/slowo-SWAG, online 26.11.2017.

Oxford English Dictionary, http://www.oed.com/view/Entry/389023\#eid301493073, online 26.11.2017.

Quote Investigator, https://quoteinvestigator.com/2012/05/24/live-once/, online 26.11.2017. 